\title{
KONDISI SOSIAL EKONOMI BURUH KELUARGA PENGRAJIN BATU BATA
}

\author{
Gietha Putri Aroem \\ Magister Ilmu Penyuluhan Pembangunan/Pemberdayaan Masyarakat Universitas Lampung, \\ giethaputriaroem@gmail.com \\ Tubagus Hasanuddin \\ Magister Ilmu Penyuluhan Pembangunan/Pemberdayaan Masyarakat Universitas Lampung, \\ tb_sijati@yahoo.com
}

\begin{abstract}
Limited employment opportunities encourage people to look for other alternatives to find income to meet their family's needs. One of these alternatives is to become a brick production worker. The purpose of this study was to determine the socio-economic conditions of brick craftsmen workers'family. The research was conducted in Campang Raya Village, Sukabumi District, Bandar Lampung City from November to December 2019. The respondents were 15 people who were brick craftsmen who were determined purposively. Data analysis was performed by qualitative descriptive analysis. The results showed that the masonry workers were of productive age (100\%), most of them (67\%) had a low level of education. Average net income of IDR 3,320,000 - IDR 3,433,000 per month with a monthly per capita income of 1,106,000, - -Rp 1,147,000, - not meeting the UMR standard of Bandar Lampung City of IDR 2,445 .141, - Family brick craftsmen still do not get good housing facilities in the form of unsuitable housing, poor road facilities to the dwelling, and water sources that are difficult to obtain. The health facilities used for treatment is the puskesmas, the families of brick craftsmen workers do not have health insurance.
\end{abstract}

\section{Keywords:}

Brick Craftsman, Family, Income

\begin{abstract}
Abstrak
Terbatasnya lapangan pekerjaan mendorong masyarakat mencari alternatif lain dalam mencari pendapatan untuk memenuhi kebutuhan keluarganya. Salah satu alternatif tersebut adalah dengan menjadi buruh produksi batu bata. Tujuan penelitian ini adalah untuk mengetahui kondisi sosial ekonomi keluarga buruh pengrajin batu bata. Penelitian dilakukan di Kelurahan Campang Raya, Kecamatan Sukabumi, Kota Bandar Lampung dari bulan November - Desember tahun 2019. Responden adalah buruh pengrajin batu bata yang ditentukan secara purposive berjumlah 15 Orang. Analisis data dilakukan dengan analisa deskriptif kualitatif. Hasil penelitian menunjukkan buruh pengrajin batu berusia produktif (100\%), sebagian besar (67\%) memiliki tingkat pendidikan yang rendah. Pendapatan bersih rata-rata sebesar $\mathrm{Rp} 3.320 .000,--\mathrm{Rp} 3.433 .000,-$ per bulan dengan pendapatan per kapita per bulan sebesar 1.106.000,- $\mathrm{Rp} 1.147 .000,-$ dan belum memenuhi standar UMR Kota Bandar Lampung sebesar Rp 2.445.141,- .Keluarga pengrajin batu bata masih belum mendapatkan fasilitas tempat tinggal yang baik berupa tempat tinggal belum layak, fasilitas jalan ke tempat tinggal buruk, dan sumber air yang susah diperoleh. Fasilitas kesehatan yang digunakan berobat adalah puskesmas, keluarga buruh pengrajin batu bata tidak memiliki jaminan kesehatan.
\end{abstract}

Kata Kunci:

Buruh Pengrajin Batu Bata, Keluarga, Pendapatan 


\section{PENDAHULUAN}

Kemiskinan merupakan masalah yang serius yang terjadi diperkotaaan. Kemiskinan merefleksikan ketidakcukupan pemenuhan kebutuhan hidup yang paling dasar dan ketidaklayakan kesejahteraan seseorang (LIPI, 2020). Banyak masyarakat yang berasal dari desa pindah ke kota untuk mencari pekerjaan tanpa dibekali dengan kemampuan dan pendidikan yang cukup. Hal ini menyebabkan masyarakat susah untuk mencari pekerjaan sehingga tidak mampu memenuhi kebutuhan kebutuhan keluarganya. Keadaan ini mendorong pengrajin batu bata untuk mencari alternatif lain dalam memperoleh pendapat untuk memenuhi kebutuhan rumahtangganya.

Terbatasnya lapangan pekerjaan dan kondisi pendidikan yang rendah menyebabkan pengrajin batu bata harus berusaha mencari peluang pekerjaan. Pendidikan yang rendah akan memperkecil peluang untuk mendapatkan pekerjaan (Febrina et al, 2016). Banyak masyarakat berpendidikan rendah yang mencari alternatif pekerjaan lain untuk memenuhi kebutuhan rumahtangganya seperti di Kelurahan Campang Raya, Kecamatan Sukabumi, Kota Bandar Lampung. Menurut BKKBN (2017), jumlah penduduk di Kecamatan Campang Raya mencapai 6978 jiwa dengan mata mencaharian sebagian besar adalah buruh sebanyak 2558 orang. Dari sejumlah buruh di atas dijumpai sebagian kecil buruh berprofesi sebagai pengrajin batu bata karena di Kelurahan Campang Raya memiliki kondisi tanah yang cocok untuk pembuatan batu bata. Tanah di daerah ini adalah tanah liat kuning sehingga cocok untuk dibuat batu bata. Proses pembuatan batu bata dilakukan dengan mencetak, menjemur dan membakar batu bata tersebut ke dalam tungku pembakaran. Selain itu, diperlukan bahan-bahan seperti tanah liat, solar, oli, dan kayu bakar dalam proses pembuatannya.

Pekerjaan sebagai buruh pengrajin batu bata sangat mempengaruhi kondisi perekonomian keluarga pengrajin batu bata. Penghasilan dari pembuatan batu bata akan berpengaruh terhadap kondisi sosial ekonomi dan pemenuhan kebutuhan hidup pengrajin batu bata sehari-hari. Menurut Achmad et al (2015), pendapatan yang dihasilkan menggambarkan tingkat kemampuan seseorang untuk berdaya beli sehingga dapat memenuhi kebutuhan hidupnya. Faktor yang mempengaruhi kondisi sosial ekonomi dapat berupa pendidikan, pendapatan, tempat tinggal dan alat transportasi (Aristantia et al, 2019). Selain itu, jumlah tanggungan dan kesehatan keluarga dapat mempengaruhi kondisi sosial ekonomi yang berhubungan dengan pengeluaran penghasilan untuk keluarga (Kenedi, 2017). Kondisi sosial ekonomi keluarga dapat bermanfaat dalam peningkatan taraf hidup dan kualitas hidup masyarakat (Wasak, 2012). Oleh karena itu, penelitian terhadap kondisi sosial ekonomi buruh pengrajin batu bata menarik untuk diteliti.

Tujuan penelitian ini adalah untuk mengetahui kondisi sosial ekonomi keluarga buruh pengrajin batu bata di Kecamatan Campang Raya, Kelurahan Sukabumi, Kota Bandar Lampung.

\section{METODE}

Penelitian dilakukan di Kelurahan Campang Raya, Kecamatan Sukabumi, Kota Bandar Lampung, Provinsi Lampung. Penelitian dilakukan dari bulan NovemberDesember 2019. Jumlah responden sebanyak 15 orang kepala keluarga yang ditentukan secara sengaja (purposive). 
Dalam penelitian ini menggunakan alat pengumpulan data yakni (1) Angket, (2) Observasi dan (3) Studi Dokumentasi. Analisis data yang digunakan dalam penelitian ini adalah dengan analisa Deskriptif Kualitatif. Pendekatan Deskritif kualitatif adalah metode untuk menggambarkan keadaan atau fenomena serta untuk mengetahui keadaan yang berhubungan atau sesuai adanya di lapangan (Arikunto, 2010).

Data yang diperlukan dalam kegiatan penelitian ini terdiri dari data primer dan sekunder. Data primer dikumpulkan secara langsung dari narasumber yaitu keluarga buruh pengrajin batu bata dengan teknik. Data sekunder berupa data yang sudah disajikan dalam laporan-laporan dari instansi yang terkait.

\section{HASIL PENELITIAN}

\section{Usia, Tingkat Pendidikan, dan Jumlah Tanggungan Responden}

Usia suami buruh pengrajin batu bata berkisar antara 41-53 tahun, sedangkan usia istri berkisar antara 39-48 tahun dengan ratarata jumlah tanggungan keluarga sebanyak 3-4 orang. Jumlah tanggungan keluarga dihitung dari total jumlah anggota keluarga yang masih ditanggung oleh responden. Usia suami istri buruh pengrajin batu bata dan banyaknya beban tanggungan responden tampak pada Grafik 1.

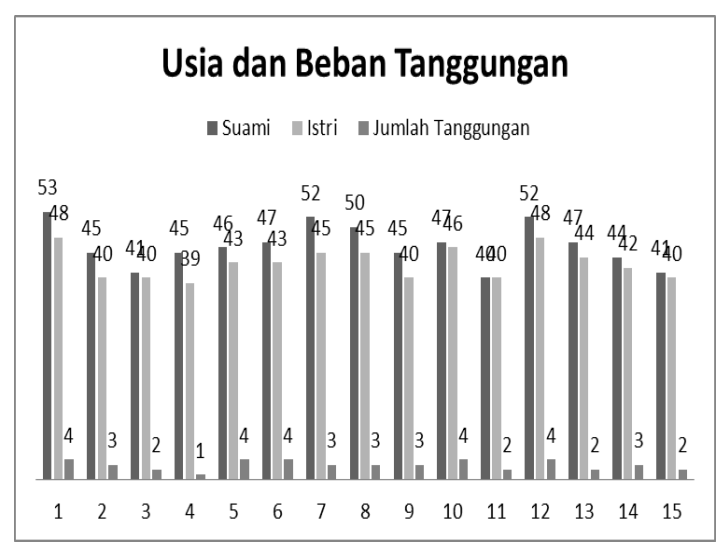

Gambar 1. Usia suami istri buruh pengrajin batu bata dan beban tanggungan keluarga

Tingkat pendidikan terendah suami pengrajin batu bata adalah tidak lulus sekolah dasar (20\%), lulus SD (47\%), dan SMP (33\%). Dari data ini maka 67\% suami masih tergolong berpendidikan rendah. Di pihak lain, tingkat pendidikan istri lebih tinggi dibandingkan dengan suami, yaitu lulus SD (40\%), lulus SMP (47\%), dan $13 \%$ sisa berpendidikan setingkat SMA. Persentase tingkat pendidikan suami istri buruh pengrajin batu bata dapat dilihat melalui tabel berikut:

Tabel 1. Tingkat pendidikan suami istri pengrajin batu bata

\begin{tabular}{lcccc}
\hline \multicolumn{1}{c}{ Tingkat } & & & & \\
Pendidikan & Suami & $\%$ & Istri & $\%$ \\
\hline Tidak lulus & 3 & 20 & 0 & 0 \\
SD & 7 & 47 & 6 & 40 \\
SD & 5 & 33 & 7 & 47 \\
SMP & 0 & 0 & 2 & 13 \\
SMA & 15 & 100 & 15 & 100 \\
\hline Jumlah &
\end{tabular}

Sumber: Data primer (2019)

Jumlah tanggungan keluarga buruh pengrajin batu bata rata-rata berjumlah 3 orang per keluarga. Berdasarkan Tabel 2 tampak bahwa semua responden keluarga buruh pengrajin batu bata memiliki 
minimal 1 orang tanggungan rumahtangga dan terbanyak berjumlah 4 orang. Tabel 2 berikut ini menunjukkan jumlah beban tanggungan rumahtangga buruh pengrajin batu bata yang diteliti.

\section{Pendapatan}

Berdasarkan pendapatannya, maka pendapatan buruh pengrajin batu bata digolongkan ke dalam dua golongan, yaitu golongan buruh pengrajin batu bata besar dan buruh pengrajin batu bata kecil. Berdasarkan penelitian yang telah dilakukan terhadap responden golongan buruh pengrajin batu bata kecil (9 orang) dan buruh pengrajin batu bata besar (6 orang) diperoleh jumlah batu bata yang dapat dihasilkan oleh buruh pengrajin batu bata tersebut bervariasi. Tabel 2 berikut ini menunjukkan jumlah rata-rata batu bata yang dihasilkan oleh buruh pengarajin batu bata tersebut.

Tabel 2. Rata-rata jumlah batu bata yang dihasilkan responden

\begin{tabular}{ccc}
\hline No & $\begin{array}{c}\text { Jumlah batu } \\
\text { bata besar } \\
\text { (buah) }\end{array}$ & $\begin{array}{c}\text { Jumlah batu bata } \\
\text { kecil (buah) }\end{array}$ \\
\hline 1 & 40000 & 60000 \\
2 & 35000 & 70000 \\
3 & 30000 & 70000 \\
4 & 35000 & 75000 \\
5 & 35000 & 70000 \\
6 & 30000 & 65000 \\
7 & & 70000 \\
8 & & 60000 \\
9 & & 75000 \\
\hline $\begin{array}{c}\text { Rata- } \\
\text { rata }\end{array}$ & 34167 & 68333 \\
\hline
\end{tabular}

Sumber: Data Primer (2019)

Berdasarkan Tabel 2 di atas tampak bahwa buruh pengrajin batu bata kecil ratarata menghasilkan sebanyak 68.000 buah, sedangkan untuk buruh pengrajin batu bata besar rata-rata menghasilkan batu bata sebanyak 34.000 buah.
Biasanya pengrajin batu bata di Kelurahan Campang Raya membakar hasilnya setiap 3 bulan sekali. Pengrajin batu bata juga harus membayar biaya sewa tanah yang tergantung dari hasil batu bata yang pengrajin batu bata buat dengan perbandingan 1:10. Misalnya pengrajin batu bata dapat menghasilkan batu bata sebanyak 50 ribu buah, maka pengrajin batu bata harus membayarnya dengan 5 ribu batu bata ke pemilik tanah. Batu bata kecil dihargai Rp 220,-/buah sedangkan batu bata besar dihargai Rp 450,-/buah. Tabel 3 berikut ini menunjukkan pendapatan yang dapat diperoleh oleh buruh pengrajin batu bata.

Tabel 3. Rata-rata Pendapatan buruh pengrajin batu bata (per 3 bulan)

\begin{tabular}{|c|c|c|}
\hline & $\begin{array}{c}\text { Batu bata } \\
\text { kecil }\end{array}$ & $\begin{array}{c}\text { Batu bata } \\
\text { besar }\end{array}$ \\
\hline \multicolumn{3}{|l|}{ Penerimaan } \\
\hline $\begin{array}{l}\text { Rata-rata batu } \\
\text { bata yang } \\
\text { dibuat selama } \\
3 \text { bulan } \\
\text { dikalikan } \\
\text { dengan harga }\end{array}$ & $\begin{array}{l}68000 \text { buah } x \\
\text { Rp } 220,- \\
=\text { Rp } \\
14.960 .000,-\end{array}$ & $\begin{array}{c}34000 \text { buah } x \\
\text { Rp 450,- } \\
=\text { Rp } \\
15.300 .000,-\end{array}$ \\
\hline \multicolumn{3}{|l|}{ Biaya } \\
\hline $\begin{array}{l}\text { Biaya } \\
\text { Operasional } \\
\text { (kayu, oli, } \\
\text { bensin, sewa } \\
\text { dll) }\end{array}$ & $\begin{array}{c}\mathrm{Rp} \\
5.000 .000,-\end{array}$ & $\begin{array}{c}\mathrm{Rp} \\
5.000 .000,-\end{array}$ \\
\hline \multicolumn{3}{|l|}{ Pendapatan } \\
\hline $\begin{array}{l}\text { pendapatan } \\
\text { bersih per } 3 \\
\text { bulan }\end{array}$ & $\begin{array}{c}\mathrm{Rp} \\
9.960 .000,-\end{array}$ & $\begin{array}{c}\mathrm{Rp} \\
10.300 .000,-\end{array}$ \\
\hline $\begin{array}{l}\text { Pendapatan } \\
\text { bersih per } \\
\text { bulan }\end{array}$ & $\begin{array}{c}\mathrm{Rp} \\
3.320 .000,-\end{array}$ & $\begin{array}{c}\mathrm{Rp} \\
\text { 3.433.000,- }\end{array}$ \\
\hline $\begin{array}{l}\text { Pendapatan } \\
\text { per kapita per } \\
\text { bulan }\end{array}$ & $\begin{array}{c}\mathrm{Rp} \\
1.106 .000,-\end{array}$ & $\begin{array}{c}\mathrm{Rp} \\
1.147 .000,-\end{array}$ \\
\hline
\end{tabular}

Sumber: Data primer diolah (2019) 
Dari Tabel 3 di atas tampak bahwa pendapatan bersih pengarajin batu bata kecil dan batu bata besar tidak menunjukan perbedaan yang berarti. Pendapatan bersih perbulan untuk satu keluarga rata-rata berkisar Rp 3.320.000,- - Rp 3.433.000,- .

\section{Pemenuhan Kebutuhan Sehari-hari}

Pemenuhan kebutuhan sehari-hari keluarga buruh pengrajin batu bata dapat dilihat dari tercukupinya konsumsi pangan dan sandang serta kebutuhan lain dari hasil pendapatan yang diperoleh buruh pengrajin batu bata. Tabel 4 berikut ini memperlihatkan tingkat pemenuhan kebutuhan hidup seharihari buruh pengarajin batu bata.

Tabel 4. Tingkat Pemenuhan Kebutuhan sehari-hari responden

\begin{tabular}{lcc}
\hline \multicolumn{1}{c}{ Jawaban } & Jumlah & $\%$ \\
\hline Terpenuhi & 5 & 33,3 \\
Kurang & 10 & 66,7 \\
Terpenuhi & 15 & 100 \\
\hline \multicolumn{1}{c}{ Jumlah } &
\end{tabular}

Sumber: Data primer (2019)

Berdasarkan Tabel 4 di atas tampak bahwa sebanyak 33,3 \% responden buruh pengrajin batu bata mengungkapkan penghasilan pengrajin batu bata sudah dapat memenuhi kebutuhan hidup pengrajin batu bata, sedangkan $66,7 \% \quad$ sisanya mengungkapkan bahwa kebutuhan pengrajin batu bata masih kurang terpenuhi jika hanya mengandalkan penghasilan dari pembuatan batu bata.

\section{Keadaan dan Fasilitas Tempat Tinggal}

Berkaitan dengan keadaan dan fasilitas tempat tinggal, maka pekerja buruh pengarajin batu bata tersebut sebagian besar masih menyewa. Pengrajin batu bata menyewa tanah dan membangun tempat tinggal sementara yang berupa tempat tinggal darurat semi permanen. Lamanya pengrajin batu bata bertempat tinggal di rumah sementara tersebut berkaitan dengan masih dapat tidaknya tanah yang ada di sekitar rumah dapat dibuat batu bata. Jika tanah di sekitar rumah sementara tersebut tidak dapat lagi digunakan untuk membuat batu bata, maka pengrajin batu bata akan berpindah tempat mencari tempat yang lain. Tabel 5 berikut ini memperlihatkan kondisi rumah buruh pengrajin batu bata.

\section{Tabel 5. Kondisi Rumah}

\begin{tabular}{lcc}
\hline $\begin{array}{l}\text { Kondisi } \\
\text { Rumah }\end{array}$ & Jumlah & $\%$ \\
\hline $\begin{array}{l}\text { Permanen } \\
\text { Semi }\end{array}$ & 4 & 27 \\
Permanen & 11 & 73 \\
\hline \multicolumn{1}{c}{ Jumlah } & 15 & 100 \\
\hline
\end{tabular}

Sumber: Data primer (2019)

Sebanyak $73 \%$ buruh pengrajin batu bata memiliki kondisi rumah semi permanen sedangkan $27 \%$ sisanya sudah permanen. Bangunan semi permanen tersebut masih terbuat dari papan kayu dan lantainya masih tanah, sedangkan yang dimaksud dengan rumah permanen adalah rumah tersebut sudah memiliki pondasi yang kokoh. Sementara pada fasilitas tempat tinggal, jalan ketempat tinggal pengrajin batu bata masih tanah dan bebatuan dan belum beraspal dan fasilitas air sangat susah diperoleh pada musim kemarau.

Berkaitan dengan kesehatan keluarga, maka pengrajin batu bata memiliki jasmani yang sehat untuk beraktifitas sehari-hari akan tetapi tidak memiliki jaminan kesehatan. Tabel 6 
menunjukkan fasilitas kesehatan yang digunakan oleh responden untuk berobat.

Tabel 6. Fasilitas kesehatan yang digunakan responden untuk berobat

\begin{tabular}{ccc}
\hline $\begin{array}{l}\text { Jenis fasilitas } \\
\text { kesehatan }\end{array}$ & Jumlah & $\%$ \\
\hline $\begin{array}{c}\text { RS/Klinik } \\
\text { Puskesmas }\end{array}$ & 0 & 0 \\
\hline Jumlah & 15 & 100 \\
\hline
\end{tabular}

Sumber: Data primer (2019)

\section{Alat Transportasi}

Alat transportasi yang dimiliki oleh pengrajin batu bata adalah sepeda motor. Semua pengrajin batu bata memiliki motor untuk menunjang mobilitas keluarga dalam kehidupan sehari-hari. Status kepemilikan kendaraan bermotor pengrajin batu bata adalah milik sendiri, namun masih ada yang menyicil dan umumnya pengrajin batu bata membeli motor bekas.

\section{PEMBAHASAN}

\section{Keadaan Sosial Ekonomi Buruh Pengrajin Batu Bata}

Buruh pengrajin batu data yang bekerja merupakan pasangan suami istri yang menghabiskan waktu seharian untuk membuat bata. Karakteristik keluarga buruh batu bata dalam penelitian ini yaitu memiliki usia produktif untuk bekerja berkisar antara 39-53 tahun. Menurut BPS (2015), usia produktif adalah usia yang berkisar antara 15-64 tahun. Usia ini dapat mempengaruhi produktivitas seseorang untuk bekerja. Pengrajin batu bata di daerah penelitian bekerja berkisar antara 5-6 jam per hari.

Tingkat pendidikan buruh pengrajin batu bata masih tergolong rendah, sebanyak $67 \%$ suami buruh pengrajin batu bata tidak lulus dan hanya setingkat SD. Hal ini karena kondisi ekonomi pengrajin batu bata yang tidak mendukung (miskin) sehingga mengakibatkan pengrajin batu bata lebih memilih untuk bekerja dibandingkan melanjutkan sekolah. Tingkat pendidikan yang rendah ini mengakibatkan pengrajin batu bata memutuskan bekerja sebagai buruh batu bata. Menurut penelitian Hindun (2019), pendidikan sangat berpengaruh dalam penyerapan tenaga kerja. Kualitas pendidikan yang tinggi akan mempengaruhi kualitas sumber daya manusianya sehingga penyerapan tenaga kerja lebih optimal. Oleh karena itu semakin rendah tingkat pendidikan seseorang semakin terbatas lapangan pekerjaan yang tersedia.

Pendapatan per kapital keluarga per bulan sebesar Rp. 1.106.000,- - Rp 1.147.000,- masih belum memenuhi standar UMR sebesar Rp. 2.445.141,-. Jumlah per kapital keluarga dihitung dari seberapa banyak anggota keluarga yang harus ditanggung. Jumlah tanggungan keluarga rata-rata berjumlah 3 orang per keluarga. Pendapatan pengrajin batu bata belum tentu cukup untuk memenuhi kebutuhan seharihari. Menurut Sumardi dan Evers dalam Subaidi et al (2015), kebutuhan sehari-hari dapat berupa kebutuhan konsumsi individu dan kebutuhan pelayanan sosial yang berguna untuk kelangsungan dan kesejahteraan manusia. Kebutuhan keluarga buruh pengrajin batu bata dalam penelitian ini mengungkapkan bahwa pendapatan yang diperoleh dari hasil pembuatan batu bata digunakan untuk kebutuhan dasar utama berupa pangan dan biaya hidup lainnya.

Tingginya konsumsi untuk pemenuhan kebutuhan sehari-hari dapat dipengaruhi oleh banyaknya jumlah orang yang ditanggung dalam keluarga. Hal ini yang menyebabkan pemenuhan kebutuhan 
kurang maksimal. Apabila jumlah tanggungan sedikit, maka pemenuhan kebutuhan akan terpenuhi (Yanti dan Murtala, 2019). Jumlah tanggungan keluarga umumnya akan berpengaruh terhadap tingkat pengeluaran keluarga tersebut (Purwanto dan Taftazani, 2018). Keadaan ini dapat dilihat pada Tabel 4 tentang pemenuhan kebutuhan yang menunjukan bahwa 66,7 \% keluarga buruh pengrajin batu bata masih kurang tercukupi dalam memenuhi kebutuhan keluarganya dengan tanggungan pengrajin batu bata ratarata berjumlah 3 orang per keluarga.

Keluarga buruh pengrajin batu bata di daerah penelitian menyatakan bahwa kebutuhan sehari-hari yang tidak tercukupi mengakibatkan buruh pengrajin batu bata harus meminimalisir pengeluaran dan terkadang juga harus berhutang ke warung. Keadaan ini selalu dilakukan oleh keluarga buruh pengrajin batu bata demi memenuhi kebutuhan hidupnya.

Keadaan dan fasilitas tempat tinggal juga masih belum tercukupi dengan baik. Hal ini dapat dilihat dari keadaan rumah yang masih semi permanen, sulitnya akses transportasi karena jalan tempat tinggal masih tanah dan bebatuan. Buruh pengrajin batu bata juga kesulitan mendapatkan air saat musim kemarau padahal pengrajin batu bata sangat membutuhkannya dalam pembuatan batu bata dan kebutuhan sehari-hari. Pengrajin batu bata di daerah penelitian mengungkapkan bahwa ketersediaan air sangat sulit saat musim kemarau sehingga kegiatan produksi menjadi terhambat.

Pada fasilitas kesehatan semua keluarga buruh pengrajin batu bata biasanya membawa keluarganya yang sakit ke puskesmas. Hal ini karena jarak puskesmas relatif dekat dan harga berobat di puskesmas tergolong murah. Meskipun demikian buruh pengrajin batu bata mengungkapkan bahwa bila sakit yang dirasa tidak parah, keluarga buruh pengrajin batu bata lebih memilih untuk membeli obat yang ada diwarung karena lebih terjangkau. Berdasarkan hasil penelitian, keluarga buruh pengrajin batu bata tidak memiliki jaminan kesehatan yang dapat menyebabkan pengawasan terhadap kesehatan masih rendah dan tidak terjaga. Padahal menurut Suryono (2018), jaminan kesehatan merupakan kebijakan publik yang berorientasi kepada pencapaian kesejahteraan sosial dalam pemenuhan kebutuhan dimasyarakat.

Keadaan sosial ekonomi yang ada di masyarakat akan mempengaruhi kesejahteraan sosialnya. Keadaan keluarga pengrajin batu bata masih belum mendapatkan kualitas hidup yang baik. Hal ini sejalan dengan penelitian yang telah dilakukan oleh Sari dan Pratiwi (2018) bahwa masyarakat yang belum memiliki kualitas hidup yang baik dapat dilihat dari keadaan kesejahteraan sosial yang ada di masyarakat berupa kualitas air yang diperoleh, rumah yang ditempati, dan kondisi rumah yang didiami.

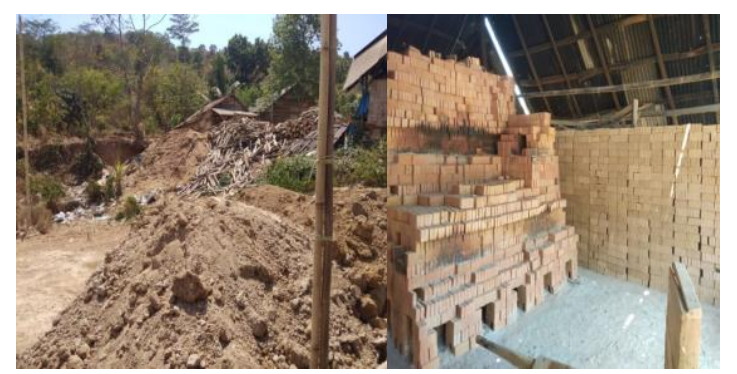

Gambar 2. Kondisi Lingkungan Buruh Pengrajin Batu Bata

\section{KESIMPULAN}

Berdasarkan penelitian yang telah dilakukan dapat disimpulkan bahwa buruh pengrajin batu bata di Kelurahan Campang Raya, Kecamatan Sukabumi, Kota Bandar 
Lampung termasuk dalam usia produktif (100\%), pendidikan formal masih tergolong rendah masih ada yang tidak lulus SDA dan hanya pada tingkatan SD sebesar 67\%, pendapatan bersih keluarga rata-rata per bulan sebesar Rp 3.320.000,- - Rp 3.433.000,dengan pendapatan per kapital per bulan sebesar Rp. 1.106.000,- - Rp 1.147.000,belum memenuhi standar UMR Kota Bandar Lampung sebesar Rp 2.445.141,-. Secara kualitatif, berdasarkan persepsi, $66,7 \%$ buruh pengrajin batu bata memaknai penghasilan yang didapat masih kurang tercukupi untuk memenuhi kebutuhan sehari-hari. Keadaan dan fasilitas tempat tinggal juga masih belum tercukupi dengan baik dilihat dari tempat tinggal semi permanen, akses jalan buruh, dan ketersediaan air sulit saat kemarau. Fasilitas kesehatan yang digunakan berobat yaitu puskesmas, keluarga buruh pengrajin batu bata tidak memiliki jaminan kesehatan.

\section{DAFTAR PUSTAKA}

Achmad, B., Diniyati,D., Fauziyah, E., dan Sulistyawati, T. (2015). Analisis Faktor-Faktor Penentu Dalam Peningkatan Kondisi Sosial Ekonomi Petani Hutan Rakyat Di Kabupaten Ciamis. Jurnal Penelitian Hutan Tanaman 11 (3): 63-79.

Arikunto, S. (2010). Prosedur Penelitian Suatu Pendekatan Praktik. Jakarta: Rineka Cipta.

Aristantia, D., Sikidin, W. Hartanto. (2019). Kondisi Ekonomi Buruh Perempuan PT. Mitratani Dua Tujuh Kabupaten Jember. Jurnal Pendidikan Ekonomi 13 (1):116-122.

BKKBN. (2017). Profil Campang Raya.

Diakses dari http://kampungkb.bkkbn.go.id/profil e/2105.

BPS. (2015). Indikator Kesejahteraan

Rakyat 2015. Jakarta: Badan Pusat Statistika.

Febrina, L., Normelani, E., Hastuti, K. P. (2016). Identifikasi Kondisi Sosial Ekonomi Penduduk di Kelurahan

Kelayan Luar Kecamatan

Banjasmasin Tengah. Jurnal

Pendidikan Geografi 3(2):42-60.

Hindun. (2019). Pendidikan, Pendapatan

Nasional, dan Penyerapan Tenaga

Kerja di Indonesia. Jurnal

Pendidikan Ekonomi Manajemen

dan Keuangan 3(1):15-22.

Kenedi, J. (2017). Aktifias Istri Pencetak

Batu Bata Membangun Ekonomi

Keluarga dan Faktor-Faktor yang

Mempengaruhinya di Naga Tanjung

Betung Kabupaten Pasaman.

Humanisma: Journal of Gender

Studies 1 (1): 87-95.

LIPI. (2020). Garis Kemiskinan dan

Kemiskinan Ecopos/Carunia Mulya

Firdausy (Ed). Jakarta: LIPI Press.

Purwanto,A., dan Taftazani, B.M. (2018).

Pengaruh Jumlah Tanggungan

Terhadap Tingkat Kesejahteraan

Ekonomi Keluarga Pekerja K3L

Universitas Padjadjaran. Jurnal

Pekerjaan Sosial 1(2): 33-43.

Sari, M. E.P., dan Pratiwi, D.A. (2018).

Faktor-faktor yang Mempengaruhi

Kesejahteraan Hidup Masyarakat

Suku Laut Pulau Kota Batam.

Jurnal Trias Politika 2(2):137-152.

Subaidi., Sidiq, M., Rahmawati, A. (2015).

Peran Istri Nelayan Dalam

Pemenuhan Kebutuhan Keluarga.

Ilmu Kesejahteraan Sosial

Universitas Jember 1(1): 1-16. 
Suryono, A. (2018). Kebijakan Publik untuk Kesejahteraan Rakyat. Jurnal Ilmiah Ilmu Administrasi 6 (2): 98-102.

Wasak, M. (2012). Keadaan Sosial Ekonomi Masyarakat Nelayan Di Desa Kinabuhutan Kecamatan Likupang Barat, Kabupaten Minahasa Utara, Sulawesi Utara. Pasific Journal 1 (7): 1339:1342.

Yanti, Z., dan Murtala. (2019). Pengaruh Pendapatan, Jumlah Anggota Keluarga, dan Tingkat Pendidikan Terhadap Konsumsi Rumah Tangga di Kecamatan Muara Dua Kota Lhokseumawe. Jurnal Ekonomika Indonesi 8(2):72-81. 